\title{
Exploration on Teaching Reform of Sculpture Course in Art Design Major in Colleges and Universities
}

\author{
Sha Cai
}

\author{
School of Arts of Xi'an University, 710065
}

\begin{abstract}
Keywords: Art design major in colleges and universities; Sculpture course teaching; Reform exploration
\end{abstract}

\begin{abstract}
With the development of China's social and economic construction, sculpture course teaching has attracted wide attention from all walks of life. However, at present, many of our colleges and universities have the problems of teaching and practical use of sculpture teaching in art design major, which seriously affects the teaching quality of sculpture course in art design major, and its teaching program needs to carry out positive reform and exploration. This paper will discuss the teaching content, teaching idea and teaching mode of sculpture course of the art design major in domestic colleges and universities, and put forward the effective teaching reform plan according to the existing problems, hoping to be helpful to the art and design education of our country

In colleges and universities, art and design major is a comprehensive and highly interdisciplinary specialty, which covers a wide range, including art, decorative arts, garden art, sculpture art, architectural knowledge, design genre and human psychology and other professional fields. Sculpture is one of the main courses in the art design major. The sculpture's modeling language and space are very strong. It can exercise the students' knowledge and understanding of space. The teaching of sculpture has great influence. Therefore, the teaching of sculpture in the art design major of colleges and universities should focus on cultivating students' aesthetic and design consciousness. The focus of teaching course should be on the cultivation of humanistic consciousness, beauty, space and artistic style. However, the most significant problem in the teaching of sculpture in most of our universities' art major and part of art academy is the long-term teaching mode, teaching content and teaching scheme of the Academy of Fine Arts. In the course, students spend much time for clay sculpture and sketch task in most of the classes, which doesn't fit the actual needs of the students, but blindly let them self-exploration, resulting in encountering creative bottlenecks for a lot of students in the learning process. The following research will start a brief analysis closely around the sculpture curriculum reform ideas for art design major in colleges and universities.
\end{abstract}

\section{The Sculpture Teaching Reform Ideas of Art Design Major in Colleges and Universities}

In recent years, sculpture course teaching mode and teaching purposes of art design major in the domestic institutions of higher learning have appeared significant changes. Knowledge structure of art design major becomes more and more complex and diversified, involving a wide range, leading to a greater difference of the sculpture course among students in art design major, which is a big difficulty for sculpture curriculum of art design major to achieve the teaching purpose in colleges and universities. In recent years, the social economy develops rapidly, science and technology have a continuous improvement, and the ideological and cultural increasingly mature. In this information age, art design course knowledge will be inevitably combined with information. In order to fundamentally promote the development of teaching work, it needs to proceed in the knowledge model, and comprehensive development of innovative information knowledge model is the primary work. Sculpture courses teachers of art design major need continuous self-learning, update teaching ideas, and improve the educational philosophy, so as to significantly improve the teaching effect. They need to recognize the definition of teaching content without much emphasis on theory or practice, and should reasonably combine the actual needs and actual level of students and constantly perfect both theory and practice. Sculpture is one of the most important constituent elements of the design of contemporary art works and the design of the environmental art design landscape. It is a 
test of the sculptor's ability to design and the level of spatial planning. Sculpture can enhance the overall aesthetics of environmental art. Therefore, the teachers should focus on the environmental landscape of the performance elements and sculpture of the visual function in the teaching contents. Different types of sculptures represent different cognitive space, understanding space and aesthetic space, which can actively inspire the viewer's aesthetic consciousness, and directly make students feel the charm of sculpture and the content the sculpture author want to express through the works during the observation. This is of great significance for teaching effect of sculpture course in art design major in the domestic institutions of higher learning.

In recent years, the number of art and design students in many colleges and universities in China has growth trend compared with that in the previous years, and the number of the majority of classes has increased dramatically, which is a big challenge for teachers. Many students have not received professional and systematic training before they are enrolled, and the ability of sketches of character and selected still life is the ability of art and design professionals. Students' weak basic abilities is relatively difficult part for course teaching of art design major, which is a disadvantage for teachers to achieve teaching purposes. But at the same time, the rapid development of science and technology and information technology has infused into the contemporary art and design teaching, which is undoubtedly a good thing for the students. Besides, students' thoughts have become more active and agile under the influence of the information age, which is beneficial for the ultimate teaching effect. In order to improve the overall ability of the sculpture, artistic ability and professional quality of students, teachers need to improve the teaching mechanism and teaching mode, and reform teaching content according to the actual needs and practical ability of students.

\section{Teaching Reform of Sculpture Course in Art Design Major of Colleges and Universities}

In recent years, many educational and scientific research institutions at home and abroad have started to explore the educational philosophy and educational model of the sculpture course in art design major, aiming at the practical application of the innovative sculpture curriculum theory and the overall innovation to optimize the teaching effect. At present, some of the domestic art and design colleges and universities have introduced the Bauhaus teaching model, and the effect is remarkable, which greatly improves the teaching achievement of the sculpture course and promotes the learning ability of the students in the sculpture course of art design major. At present, many educational institutions and educational systems in colleges and universities are constantly innovating and perfecting. The disciplines of art design majors are faced with many difficulties. The teachers of art and design specialty should study the advanced teaching experience and teaching model of excellent universities both at home and abroad, and integrate into their own teaching based on the actual situation of students, thus to enhance the overall teaching level of the sculpture.

\section{Paying Attention to the Combination of Theory and Practice Teaching}

In the art design professional sculpture course, the sculpture practice skills training is the basis of the course, and then deepen the aesthetic training and theoretical teaching. In order to enhance the overall integration of teaching systems and functional diversification, professional techniques are required to emphasize in the sculpture course, and the optimization of educational resource allocation requires the education of theoretical knowledge in the sculpture curriculum. Therefore, teachers in the art design professional sculpture courses need to combine the professional technique training and education of theoretical knowledge organically to emphasize the importance of theoretical knowledge, and impart theoretical knowledge with picture-based teaching method. Teaching with illustrations and pictures can not only solve problem of vapidity in the theory course, but also inspire students 'enthusiasm for learning, which greatly reduce the boring sense of the theory of sculpture course. Meanwhile, adding excellent works for appreciation in the art design professional sculpture will not only arouse students' interest in sculpture, but also cultivate students' aesthetic consciousness and comprehensive appreciation ability. Appreciation, interpretation and imitation of these excellent works during the study will be able to enhance the self-recognition of 
the sculpture and appreciation of the ability of art design professional sculpture students and understand the nature of the sculpture course more thoroughly, thus can strengthen the flexibility and practicality of professional skills in the actual production.

\section{The Choice of Advanced Teaching Methods and Training Mode}

In the domestic institutions of higher learning, art and design professional sculpture courses are more different than other professional courses. Students cultivate a multi-dimensional space imagination, aesthetic awareness and innovation in the sculpture course learning. Professional teachers in the sculpture course should first perform practical training, and then impart theoretical knowledge. This teaching mode can improve the overall quality and practical ability of students, and can greatly improve the enthusiasm of students to learn while training the self-learning ability of students. This kind of teaching mode has stronger pertinence and purposiveness and can avoid teaching problems of teachers and passive learning of students. This system of teaching mode allows students to hold the problem to learn, but also contribute to the learning effect. Teachers can also allow students to independently design and product highly decorative animals or characters sculpture, which not only allows students to master the argillation in practical operative and enhance the professional quality, but also comprehensively improve the enthusiasm of students and creative sense of innovation in self-design process, which is of great significance for the teaching course of sculpture. At the same time, this practical training is more useful than the traditional classroom teaching to practice students' design level and practical ability. Students are able to effectively practice the sculpture material collection, sculpture subject collection, sculpture material mastery, sculpture design and sculpture technology, which can improve the students' creative ability and professional experience. This shows that the practical training application is of great influence for the students in the sculpture course. Teachers using this teaching method can guide students to learn independently rather than passive lectures and help students develop a good learning attitude while greatly improving the student's professional ability.

\section{Taking a Combination of Teaching Evaluation Model}

The combination of teaching evaluation mechanism is used in the teaching of art and design professional sculpture course. This teaching mechanism can not only give students to create a positive learning atmosphere, but also bring the authenticity in classroom teaching. Students can choose sculpture design theme, content, form and materials based on their own real, and produce sculpture independently according to their own ability to cultivate their creative ability and enhance their imagination. Evaluation after the examination is very important. The examination is intended to allow students to fully understand their professional level and the existence of the problem, and after the examination, the evaluation mainly analyze the shortcomings of students to enable students to discover their own deficiencies and defects and timely remedy, which has a great influence on the overall quality of teaching. At the same time, the teaching model of adding actual subject training in the teaching can also make students perform the self-evaluation while independently producing sculpture, and can evaluate with students around, and finally get the professional evaluation of teachers. This can not only know their shortcomings from different angles, but also let art design professional sculpture course have vitality.

\section{Focusing on the Combination of Communication and Knowledge Update}

In the teaching of the sculpture course, the post-class communication is of great significance, which not only make students consolidate the professional knowledge of the sculpture course after class, but also let the students communicate with each other directly and learn from each other. This is very significant for students to summarize after class and improve self-awareness and self-improvement. In the post-class communication, teachers can cultivate students' ability to communicate and self-evaluation ability. Teachers should encourage students to participate in a lot 
of social public sculpture competition or professional environmental designer's academic symposium and other meaningful activities to improve their professional quality and exercise their own sculptural ability, which can effectively promote the effect of sculpture teaching. Teachers themselves should also continue to innovate and optimize the content of sculpture courses, and to update the curriculum knowledge model and curriculum structure according to social changes and the development of science and technology. With the progress of science and technology, art design sculpture materials appear a lot of emerging materials that are no longer limited to the traditional stone, wood, clay and bronze. At present, steel, glass, gel and high-tech molecular polymers and other materials are widely used in sculpture. Besides, the sculpture is not limited to the unity of the material. In a work, different materials combined together with collision of aesthetic feeling are also very fantastic. With the sculpture materials becoming more and more diversified, the types are also richer and richer. Teachers need to grasp the development of real-time, and constantly enrich their own professional knowledge and integrate into their own teaching.

\section{Conclusion}

In the art design specialty of colleges and universities in China, the teaching program of the sculpture curriculum needs to reform and innovate continuously. The teachers need to adopt different teaching modes to solve the problems in the teaching of sculpture, and focus on cultivating the artistic design concept and improving the teaching content and teaching programs, so that the aesthetic, design awareness, imagination, perception, sense of space and practical ability of students can be fully improved, making great improvement of teaching effectiveness of sculpture courses. In this era of lack of design talent, only do a good job of college art design professional course teaching can fundamentally solve the problem of lack of design talent. Teaching programs and teaching models need to advance with the times, fit the actual situation of the students to reform, innovate and improve, thus to cultivate a high standard of design talent to meet the development of China's social and economic development of high-quality talent needs.

\section{References}

[1] N.W. Li, D.H. Ye: Exploring the Teaching Reform of Computer Aided Design Course of Art Design Specialty with Creative as the Core. Education and Vocation, Vol. 12 (2014), p. 149. (In Chinese)

[2] H.Z. Xi, L.Y. Lu: Exploration on the Teaching Reform of Undergraduate Major Technical Courses in Colleges and Universities - Taking the Course of "Ecological Design and Technical Construction" as an Example. Internet Fortune, Vol. 04 (2010), p. 13. (In Chinese)

[3] Y. Xu, H.M. Huang: The Teaching Reform of Practical Course of Art Design Specialty in Colleges and Universities - Taking Environmental Art Design Specialty as an Example. Art Science and Technology, Vol. 04 (2012), p. 119. (In Chinese)

[4] Y.Q. Cui, Q.H. Diao: Thinking and Practice on Teaching Reform of Photoshop Course in Art Design Specialty in Colleges and Universities. Art Research, Vol. 04 (2014), p. 126. (In Chinese)

[5] S.Q. Bai: A Case Study on the Teaching Reform of the Basic Course of Art Design in Colleges and Universities - Taking "Two-dimensional Design Basis" and "Three-dimensional Design Basis" Course of Central Academy of Fine Arts as an Example. Intelligence, Vol. 24 (2016), p. 181. (In Chinese)

[6] C.H. Zha, B.H. Zhang: Research on the Teaching Design of Aerobics Online Course Based on Resource-based Learning - Exploration on Teaching Reform of Technical Courses of Physical Education Major in Colleges and Universities. Journal of Capital Institute of Physical Education, Vol. 02 (2007), p. 31. (In Chinese)

[7] B. Sun: Research on the Reform of Software Teaching Model of Art Design Specialty in Colleges and Universities Based on Innovative CG Talents Training. Art Education Research, Vol. 23 (2014), p. 158. (In Chinese) 
[8] Y.C. Wu: Exploration on Teaching Reform of "Cross - border" Course of Art Design Specialty in Higher Vocational Education. Journal of Huaihai Institute of Technology, Vol. 23 (2012), p. 103. (In Chinese)

[9] P. Gao: From Practice to Practice - Exploration on Teaching Reform Method of Art Decoration Course Design. Modern Decoration (Theory), Vol. 09 (2014), p. 206. (In Chinese)

[10]Q.S. Zhang: Reform and Exploration of Teaching Mode of Landscape Architecture Design Course for Environmental Art Design (Landscape) in Higher Vocational Colleges. Contemporary Education Research and Teaching Practice, Vol. 09 (2016), p. 219. (In Chinese)

[11] M. Wang: Practice and Exploration on the Teaching Reform of the Basic Course of Art Design Specialty - Taking the Course of Digital Media Art as an Example. Art Education, Vol. 08 (2015), p. 251. (In Chinese)

[12]Z.H. Li: Exploration and Practice of Teaching Reform of Costume Art Design Specialty Taking "Costume Material Science" Course as an Example. Journal of Shaoguan University, Vol. 07 (2016), p. 134. (In Chinese)

[13] L.Y. Xin: From Realism to Decoration - A Preliminary Study on the Teaching Reform of Color Course in Art Design Specialty in Colleges and Universities. Art Education Research, Vol. 21 (2014), p. 140. (In Chinese) 